\title{
The Effect of Austerity Packages on Government Popularity During the Great Recession
}

\author{
Abel Bojar ${ }^{1 \star}$ (D), Björn Bremer ${ }^{2}$, Hanspeter Kriesi ${ }^{1,3}$ (D) and Chendi Wang ${ }^{1}$ \\ ${ }^{1}$ European University Institute, Florence, Italy, ${ }^{2}$ Max Planck Institute for the Study of Societies, Cologne, Germany and \\ ${ }^{3}$ Laboratory for Comparative Social Research, National Research University Higher School of Economics, Russian Federation \\ *Corresponding author. E-mail: abel.bojar@eui.eu
}

(Received 8 May 2019; revised 10 May 2020; accepted 19 July 2020; first published online 21 January 2021)

\begin{abstract}
During the Great Recession, governments across the continent implemented austerity policies. A large literature claims that such policies are surprisingly popular and have few electoral costs. This article revisits this question by studying the popularity of governments during the economic crisis. The authors assemble a pooled time-series data set for monthly support for ruling parties from fifteen European countries and treat austerity packages as intervention variables to the underlying popularity series. Using time-series analysis, this permits the careful tracking of the impact of austerity packages over time. The main empirical contributions are twofold. First, the study shows that, on average, austerity packages hurt incumbent parties in opinion polls. Secondly, it demonstrates that the magnitude of this electoral punishment is contingent on the economic and political context: in instances of rising unemployment, the involvement of external creditors and high protest intensity, the cumulative impact of austerity on government popularity becomes considerable.
\end{abstract}

Keywords: austerity; fiscal consolidation; economic voting; time series analysis; government popularity; economic crisis

The economic voting literature explains the voting behavior or the ups and downs of government popularity - the Vote-Popularity function - using both objective and subjective economic indicators. The role of the economy varies across studies, but Bellucci and Lewis-Beck (2011) document that it has a strong and stable effect on government popularity (approval) across countries. In a particularly elegant study, Stimson (2004) shows that, in the United States, 'tides of consent' rise and fall with the health of the economy. The vast literature on economic voting suggests that voters hold incumbents accountable for economic outcomes (see for example, Duch and Stevenson 2008; Stegmaier, Lewis-Beck and Park 2017). Empirical studies on economic voting show that it is pervasive in 'normal' elections.

But does economic voting also take place during economic crises? The asymmetric grievances hypothesis from the literature on economic voting would suggest that the economy generally has a stronger electoral impact during bad times (Lewis-Beck and Paldam 2000). A growing literature on economic voting in the Great Recession confirms this hypothesis: incumbents have been severely punished in the polls due to the depth of the recession (for example, Bartels 2014; Bellucci 2014; Bremer, Hutter and Kriesi 2020; Hernández and Kriesi 2016; Magalhaes 2014). These studies have typically focused on election outcomes. At the time of the elections, however, voters may no longer remember the specific instances (such as policy decisions) that triggered their blame for the government, but they are likely to have integrated their assessment of specific government decisions into a 'running tally' of their evaluation of the government which influences 
their electoral choice later on. It is thus difficult to determine the extent to which governments are held responsible for policy decisions, for the poor state of the economy in general, or the relative economic situation in their country compared to other countries (Kayser and Peress 2012).

Yet voters do not need to wait for the next electoral campaign to assess the impact of economic policy decisions on their vote intentions. To clarify the attribution of responsibility to the government, we follow the lead of Marsh and Mikhaylov (2012) and move closer to crisis-related policy interventions that are directly under government control to study their effect. In a severe economic crisis such as the Great Recession, economic policy debates and decisions are expected to become more salient and less ambiguous - and therefore to directly affect vote intentions from their first mention in the news. ${ }^{1}$ This focus on policy decisions is all the more important during economic crises because in such circumstances macro-economic aggregates may not be the main reference point for voters when they assign responsibility to incumbents (for example, Bellucci 2014; Clarke and Whitten 2013). ${ }^{2}$ For various reasons (clarity of responsibility, international nature of the crisis, bounded rationality and limited knowledge of voters), economic crises present a particularly difficult cognitive environment for voters to assign responsibility and judge incumbent parties by their economic record. Yet the Great Recession compelled governments to adopt highly mediatized and hotly debated economic policies that reached and resonated more with a wider segment of the electorate than the monthly or quarterly fluctuation of macroeconomic indicators did. In this study, we thus turn from the real economy (output) to economic policy (input) in search of the aggregate-level economic vote.

We are particularly interested in the impact of a specific set of economic policies that governments implemented in the wake of the recent economic crisis on ruling-party vote intentions: austerity measures. Most governments initially adopted fiscal expansionary measures relying on some version of 'liberal' or 'emergency Keynesianism' in response to the Great Recession (Armingeon 2012; Pontusson and Raess 2012). As the crisis continued, however, governments generally turned to austerity measures. The Greek crisis erupting in early 2010 initiated this change in policy. Echoing the policy debates of the 1980s, TINA politics - 'There Is No Alternative' - became the catch phrase of economic policy once again. We focus on these austerity packages that governments introduced once 'emergency Keynesianism' gave way to the perceived imperative of economic orthodoxy in Europe.

The literature on fiscally conservative voters (Peltzman 1992) argues that such austerity policies have little electoral costs for governments that implement them (for example, Alesina, Favero and Giavazzi 2019; Alesina et al. 1998; Arias and Stasavage 2019; Brender and Drazen 2008). In this article, we revisit the question of whether austerity packages are popular by estimating their impact during the Great Recession on support for the government. We assembled a pooled time-series data set that includes monthly vote intention data for fifteen European countries from 2005 to 2015 and systematically coded austerity packages in these fifteen countries during this period. This allows us to use time-series analysis to estimate the impact of austerity packages on government popularity by treating them as intervention variables to the underlying popularity series.

The main empirical findings of this analysis are twofold. First, we show that on average, governments were indeed punished for implementing austerity policies during the Great Recession. Contrary to the literature on the fiscally conservative voter, we find that austerity packages had a significant and substantively important negative effect on government popularity. Secondly, however, we show that this effect is transient and that there is punishment in some contexts but not in

\footnotetext{
${ }^{1}$ We refer to the recession that followed the 2007-2008 financial crisis and the European sovereign debt crisis jointly as the Great Recession.

${ }^{2}$ The analysis of policy decisions also becomes more important in times of crisis because economic evaluations during such times may be characterized by a reduced variance (Fraile and Lewis-Beck 2014): if everybody ends up evaluating the state of the economy as poor, it becomes closer to a constant and can no longer explain the electoral outcome.
} 
others. Specifically, the magnitude of the political punishment declines over time, and it depends on several economic and political context conditions: it is large if unemployment is rising, if external creditors are involved and if there are widespread protests.

Next, we present our theoretical considerations about the impact of austerity packages on intentions to vote for incumbents. We specify three context conditions that we expect to shape the extent to which these policy measures affect incumbents' popularity. Then we discuss our data operationalization and empirical strategy based on advanced time-series analysis. Finally, we present the main results from the pooled analysis and a country case study of Greece, before we highlight the article's main contributions in the conclusion.

\section{Theoretical Considerations: the Impact of Austerity Packages}

To derive expectations regarding the impact of austerity packages on government popularity, we build on the existing literature. This literature, however, is surprisingly inconclusive about public preferences towards fiscal consolidation and their electoral impact. Originally, research on political business cycles assumed that voters support higher government spending and expansionary policies due to self-interest (for example, Golden and Poterba 1980; Nordhaus 1975). Several studies on the welfare state share this view. Most famously, Pierson $(1996,2001)$ argued that in an age of permanent austerity, welfare state programmes are difficult to cut due to opposition from interest groups and voters.

These arguments are contrary to an increasingly popular view that voters are fiscally conservative and that they oppose large government deficits and debt (Blinder and Holtz-Eakin 1984; Peltzman 1992). Most famously, Alberto Alesina and his co-authors argued that there is 'no evidence of a systematic electoral penalty or fall in popularity for governments that follow restrained fiscal policies' (Alesina et al. 1998, 198). This supplemented Alesina's 'expansionary fiscal contraction' thesis (for example, Alesina and Ardagna 1998; Giavazzi and Pagano 1990), which maintained that fiscal consolidations could have a positive effect on economic growth under certain conditions. Austerity may thus not be as unpopular as it is often assumed, which many other scholars have also found since then (see Alesina, Favero, and Giavazzi 2019; Arias and Stasavage 2019; Barnes and Hicks 2018; Bisgaard and Sloothus 2018; Brender and Drazen 2008).

However, Hübscher and Sattler $(2017,151)$ point out an important empirical shortcoming of this literature: vulnerable governments strategically avoid consolidations towards the end of the legislative term in order to minimize electoral punishment. Observational studies are unable to get around this 'strategic selection bias', but when welfare cuts become salient in electoral campaigns, they have a negative impact on incumbents' electoral performance (Armingeon and Giger 2008). Based on experimental evidence from five European countries, Hübscher, Sattler and Wagner (2018) show that governments' chances of re-election decrease when they propose fiscal austerity measures. In particular, the electorate overwhelmingly rejects spending cuts to achieve fiscal consolidation.

Moreover, the effects of fiscal consolidation measures may be different in times of crisis, when economic policy decisions become more salient. Talving (2017) has shown that during the Great Recession, incumbents have been punished for austerity measures. Her results from twenty-four European countries suggest that economic policy voting (sanctioning incumbents for austerity policies and rewarding them for stimulus) is a post-crisis phenomenon. She interprets these findings as European citizens growing tired of large-scale cuts, especially if these failed to bring the promised results.

Based on these findings, we expect austerity measures to have a negative effect on incumbents' popularity. By reducing government spending and/or increasing taxation, most attempts at fiscal consolidation place the burden of economic adjustment on the population, reducing citizens' disposable income. Governments justify these policies with the need to reduce government deficits and debt, but there are reasons to believe that these goals are not a priority for citizens. Public 
debt is an abstract economic concept and, apart from exceptional circumstances, its impact on citizens is opaque. Moreover, austerity was often combined with structural reforms, which causes further economic strain for a substantial part of the population. Therefore, we expect that a nontrivial share of voters desert parties that implement austerity and structural reforms (our baseline austerity hypothesis).

However, in line with previous research on economic voting and the recent crisis, we expect that this effect may be conditional (see, for example, Anderson 2007; Stegmaier, Lewis-Beck and Park 2017 on the economic vote and Bechtel, Hainmüller and Margalit 2017 on international bailouts). We highlight several economic and political features that may condition the electoral response to austerity announcements.

First and foremost, not all austerity packages inflict the same degree of economic hardship on the population, but their impact is contingent on the pre-existing magnitude of economic grievences. In particular, the economic voting literature has shown that the level of unemployment is important for the government's electoral prospects because it is the most salient economic indicator (for example, Fernández-Albertos and Kuo 2016; MacKuen, Erikson and Stimson 1992). ${ }^{3}$ If unemployment is rising, an increasing share of voters becomes dependent on government outlays, further aggravating the impact of fiscal cuts on voters' economic insecurity. Therefore, we expect an interactive dynamic between austerity episodes and this headline figure: the more voters lose their jobs and are unable to find new ones, the greater the expected electoral impact of austerity packages on incumbent parties. This is our economic conditions hypothesis.

However, even for austerity measures taken in dire economic straits, the impact may depend on the extent to which voters are able to hold incumbents responsible for the decisions. We focus here on the strand of the responsibility literature that explores external restrictions on accountability attribution. This literature suggests that in a multilevel governance structure such as the European Union (EU) and the Eurozone in particular, governments can deflect the blame for poor economic performance to supranational institutions and foreign governments, which also attenuates economic voting (Hellwig 2001; Hellwig and Samuels 2007; Jensen and Rosas 2020). The euro crisis offered opportunities for incumbents to shift the blame to external authorities in several countries where the International Monetary Fund (IMF) and the 'Troika' (which comprises the IMF, European Commission and the European Central Bank) had to intervene. Using the case of the Portuguese 2011 elections, Magalhaes (2014) showed that the extent of voters' punishment of incumbents depended on the extent to which they exclusively attributed responsibility to the national government. However, to her own surprise, Talving (2017) did not find any evidence that the electoral impact depends on shared policy-making responsibility with supranational and intergovernmental institutions.

One possible interpretation of Talving's finding is that, far from allowing the government to deflect blame (also see Kosmidis 2018), international creditors' interventions focus public attention on the dismal state of public finances that are ultimately the result of past government choices. For example, studies of the impact of IMF interventions on protest activity in different regions of the world suggest that such interventions actually increase incumbents' accountability (for example, Altiparmakis and Lorenzini 2018; Beissinger and Sasse 2014). The implication of this literature for our purposes is that when governments need to resort to external help (by the IMF or the Troika) at the price of conditionality, their failure to manage the economy becomes glaringly obvious to voters. The adoption of urgent policy measures under external pressure educates the public and provides intense lessons to the electorate about how dire the situation has become. In line with this literature, we expect external interventions to have a lasting negative effect on the popularity of incumbent governments (our external intervention hypothesis).

\footnotetext{
${ }^{3}$ Previously, inflation and unemployment have often been used as the main economic indicators. In the low-inflation context of the Great Recession, we discount inflation as an economic context condition.
} 
While austerity packages forced upon a country by external creditors are highly politicized by default, others may be less so. More generally speaking, packages differ greatly in the extent to which they touch upon well-organized vested interests, and different electorates in different periods may vary in their capacity and willingness to stage large-scale mobilization efforts against these measures. Building on Armingeon and Giger's (2008) emphasis on the salience of welfare cuts, we expect significant variation in the extent to which packages become the object of public controversy, unleashed by the government's challengers (opposition parties, public interest groups, the media or social movements). These challengers strive for the 'expansion of conflict' to an ever larger public (Schattschneider 1960[1975]): they seek to politicize the proposal by drawing the public's attention to it (by rendering it more salient), by mobilizing public resistance against it (that is, by polarizing public opinion on the proposal) and by expanding the number of actors opposed to it. ${ }^{4}$

Controversial public debates open up access to (and increase the legitimacy of) speakers and allies of the challenger with journalists and decision makers who tend to closely follow the public debates (Gamson and Meyer 1996, 288). This expansion of conflict from the institutitional to the protest arena has the potential to increase policy salience as it involves actors who conventionally stand on the sidelines of policy disputes. Put differently, protest has an important 'signaling function' (Bremer, Hutter and Kriesi 2020), which increases the political costs of controversial policies. We therefore expect that the impact of austerity policies on vote intentions depends on the politicizing strategies of the public (our politicization hypothesis).

\section{Data and Estimation Strategy}

\section{Data}

To test the impact of economic policy decisions on support for incumbents, we rely on monthly vote intention data that we systematically collected for fifteen European countries (see Appendix A-1 for polling sources). Beyond the obvious constraints of data availability, the countries were selected to ensure sufficient variation in their political and economic conditions at the time of the Great Recession and to provide a roughly representative geographical sample of the wider European space. In this spirit, we include Northern (Denmark, Finland), Anglo-Saxon (UK, Ireland), Continental (Austria, Germany, the Netherlands), Southern (Greece, Italy, Portugal and Spain) and Eastern European (Latvia, Hungary, Poland and Romania) countries that vary on a number of dimensions: their level of economic development, external imbalances and creditor-debtor position in international capital markets, party and electoral systems, and perhaps most importantly, the severity of the financial and economic crises they experienced from 2008 to 2013. Subject to data availability, our country series begin in 2005 and end in 2015 , ensuring that they cover both the pre- and post-crisis periods.

As argued above, the main advantage of vote intention data - as opposed to election vote shares - is the opportunity to track immediate aggregate-level changes in electoral prospects that may remain hidden when focusing on election results several years down the road. To provide a well-known example from the recent past, upon coming to power in June 2010, the Conservative government in the UK immediately laid out its austerity plans, which it followed up with a series of specific austerity packages. However, voters could not submit their verdict on these policies until the general election in May 2015. By strategically front-loading austerity, the Conservative government gave itself several years of leeway for other issues to take precedence in public debates. Regular monthly polling of the British electorate allows us to track voters' immediate responses beginning in the month when the policy decisions are first announced. ${ }^{5}$ We use the same approach in all fifteen countries by collecting all publicly available monthly

\footnotetext{
${ }^{4}$ For a definition of politicization that includes these three elements, see Hutter and Grande (2014).

${ }^{5}$ See Clarke, Ho and Stewart (2000) and Lebo and Young (2009) for examples of studies that use British vote intention data.
} 
polls to create fifteen country-specific time series of the average vote intentions for the parties that make up the ruling coalition in any given month. ${ }^{6}$

In order to measure the impact of policy events, we need to determine the timing of policy decisions. To do so, we first conducted a systematic newspaper-based event data analysis for fifteen countries in the international press (see Earl et al. 2004 for a methodological review). We used the New York Times, the Financial Times and the Neue Zürcher Zeitung; ${ }^{7}$ in the first step, we systematically collected all policy decisions taken by governments during the sample period. We then focused on the types of policies we are interested in - austerity packages and/or important structural reforms - and selected the ones that had the most extensive coverage as proxied by the highest article count corresponding to the same episode. A brief description of all episodes included in our analysis is available in Appendix A-2.

Next, ${ }^{8}$ we specify the functional form of their possible impact on vote intentions. We start from the interrupted time-series literature to theorize about the most appropriate functional form to model austerity packages as intervention variables to the underlying popularity time series (McDowall et al. 1980; Pankratz 1991, 7). While pulse functions model the impact of events as an immediate spike - or a spike after some lag - followed by some decay pattern, step functions model a permanent shift in the series after the occurrence of the intervention. We argue that in contrast to short-term and transitory events like political scandals, austerity packages are better conceptualized as events that have an immediate effect which can last for a longer duration because public contestation, policy implementation and the material costs span multiple months without an obvious 'end' to the episode. Lacking strong theoretical considerations about exactly how 'long' this duration is and when an episode comes to an 'end', we estimate the impact via step shifts in the series for time windows of multiple lengths, allowing for short-term (3 months), medium-term (6 months) and long-term (12 months) effects in the electoral response. In cases where multiple periods of austerity occur within the same window, we simply extend the window beyond the last austerity episode by the same window length. For instance, for the 6-month specification, if two austerity periods occur in close proximity of 3 months, the intervention window covers 9 months. Because of our dynamic specification (as explained below), one needs to keep in mind that the total effects are felt beyond the intervention window with a decay rate dictated by the autoregressive coefficient of the model (De Boef and Keele 2008).

Turning to the contextual features of the episodes, we test for the conditioning role of (a) the economic context, (b) external creditors' involvement and (c) politicization as laid out in our hypotheses. For the economic context, we employ the most commonly used measure in the economic voting literature: unemployment. ${ }^{9}$ We contend that it is the trend in unemployment, rather than its level, that best captures the current and future prospects of the economic climate and serves as a more appropriate reference point for electoral accountability. We thus use the annual change in unemployment between $t_{0}$ and $t_{-12}$ as our first contextual variable. While short-run (month-to-month) changes in unemployment are relatively small and contain little information

\footnotetext{
${ }^{6}$ In case of non-partisan technocratic governments, such as Monti in Italy and Papademos in Greece, we add up all parties' vote shares that supported the government. To test the robustness of our results, we also use support for the largest governing party only (that is, the prime minister's party) and the finance minister's party as our dependent variable (Appendix D-1).

${ }^{7}$ We chose these newspapers because they have a long-standing reputation in international reporting and, with the exception of the Financial Times (FT), they come from countries that are not covered by our study. We included the FT because it has the broadest coverage of international economic affairs.

${ }^{8}$ As a general rule, we coded the 'occurrence' of these events as the month when the measures were first announced. This is when they first appear in the mass media. Recent literature relying on experimental data and survey evidence has highlighted the role of party elites (Bisgaard and Sloothus 2018) and media frames (Barnes and Hicks 2018) in shaping fiscal preferences. Upon the initial announcement, party elites and media frames likely begin to influence electoral preferences, making it the appropriate time point for our analysis.

${ }^{9}$ See Lewis-Beck and Stegmaier $(2013,376)$ for a discussion of the main economic variables used in VP function studies. In Appendix D-3, we also present results for year-on-year growth of retail sales volume, the closest monthly proxy for economic growth, as a conditioning variable.
} 
for a typical voter, year-on-year changes offer a more accurate picture of the overall direction of the economy.

Our operationalization of the external involvement hypothesis is straightforward: we create a binary variable that is coded 1 for austerity episodes introduced as part of conditionality following external intervention, and 0 otherwise. ${ }^{10}$ This indicator variable separates packages that are introduced under direct international creditor pressure from those that are domestically driven.

To measure politicization, we rely on a novel database constructed via a semi-automated content analysis of the international press in thirty European countries (Lorenzini, Makarov and Wuest forthcoming, 2). For the purposes of this study, we selected protests directed at public economic issues (as opposed to private economic, political or other issues). We operationalize politicization by taking the monthly protest count, weighted by countries' population size to address reporting bias in favour of large countries. This weighted measure of monthly public economic protest count is our contextual variable for the politicization of austerity packages.

\section{Estimation}

Before we present our modelling approach, a short discussion of the time-series properties of our dependent variable is in order. As is well known from the time series methodology literature, non-stationary and strongly autoregressive processes $(\mathrm{AR}(1)$ coefficient $>0.9)$ can present formidable difficulties for valid inference because of the high risk of spurious regressions (De Boef 2001; Enders 2004, 4). Unit-root or long-memory processes are a common feature of political time series where shocks are permanent, and the series have no mean-reverting tendency. Vote intention data is a case in point: due to the highly persistent nature of partisan attachments, such data is likely to be more persistent than alternatives such as government approval, ${ }^{11}$ implying that shocks have a long (or even infinite) memory. In fact, a series of unit-root tests yields clear evidence that non-stationarity is present in most of our country series.

To address this issue, the standard fix of cointegrating equations is unfeasible due to the nature of our main independent variable (step-shift dummies), and the alternative of first differencing the dependent variable is undesirable because we are interested in the long-term dynamics in support for the government. ${ }^{12}$ Instead, we leverage the empirical literature on the popularity function that has already identified a number of sources that push the series away from their overall mean for an extended period of time. In contrast to many non-stationary variables used in political science and economics, one advantage of our popularity variable is that many of the sources of its non-stationarity behavior can be directly modelled instead of treating its unit-root nature as a nuisance to be removed via the standard fixes (such as first differencing). By properly identifying these country-specific sources, one can remove their effect from the individual country series to obtain a well-behaved stationary variable that is cleaned from the temporal confounders at the same time. Specifically, we filter out (a) secular trends, (b) linear and quadratic electoral cycle trends, (c) three-month-long honeymoon periods and (d) government-specific means. ${ }^{13}$ Therefore, our filtering equation for the country-specific vote intention series is:

$$
V I_{t}=\beta_{1} T_{t}+\beta_{2} E C_{t}+\beta_{3} E C_{t}^{2}+\beta_{4} H_{t}+\Sigma_{5}^{n} \beta_{i} G_{i t}
$$

where $V I$ is vote intention measured at time $t, T$ is a secular trend, $E C$ and $E C^{2}$ are the linear and quadratic popularity trends for each electoral cycle, $H$ is a three-month honeymoon after a new

\footnotetext{
${ }^{10}$ External involvement refers to both IMF bailouts and European bailouts that were administered by the Troika.

${ }^{11}$ See Pickup (2010) for an elegant theoretical and empirical discussion for a comparison.

${ }^{12}$ We provide the results for the first-differenced raw vote intention data as a dependent variable in Appendix D-2.

${ }^{13}$ See Veiga and Veiga (2004) for an example of cyclical trends in Portuguese vote intention data, Malet and Kriesi (2020) for the estimation of honeymoon effects in Italy, and Dassonneville and Lewis-Beck (2014) for the cost of ruling on a large cross-national sample.
} 
government comes to power, and $G$ denotes a set of government dummies to capture the different average popularity of different parties participating in government at any given point in time. We then use the residuals from this filtering regression, which essentially capture the parts of the vote intention series that are unexplained by temporal regularities, as the dependent variable in the study. As the influence of various temporal effects is removed from the series, one can also think of this method as a hard test of our empirical analysis: we only pick up the impacts of events that are above and beyond the regular impact of time, minimizing the risk of spurious findings. If we detect a significant impact of austerity packages in our analysis, we can safely rule out the possibility that this is due to some global or local trend affecting all governments, such as the general cost of ruling.

With our filtered dependent variable defined in this way, we proceed to estimate our intervention functions via pooled maximum-likelihood estimation. ${ }^{14}$ Another round of unit-root tests allows us to reject the null of non-stationarity in all the series and estimate a dynamic model with a lagged dependent variable (LDV). ${ }^{15}$ The generic form of our estimated models is:

$$
V I F_{i t}=\alpha_{i} V I F_{i t-1}+\beta_{1} I_{i t}+\beta_{2} C_{i t}+\beta_{3} I_{i t} C_{i t}+\varepsilon_{i t},
$$

where the dependent variable is now our filtered series for country $i$ that is modelled as a function of its lagged value, an austerity variable defined above in interaction with a contextual variable denoted by $C$, and a white noise, iid error term $(\varepsilon) .{ }^{16}$ All right-hand side variables exert their initial impact in a contemporaneous fashion with delayed effects accumulating over time at a rate dictated by the long-run multiplier (the coefficient for the LDV).

As for potential country-specific (unit) effects, it is important to note that country-specific means have been removed from the series via the filtering, so the inclusion of country fixed effects is made superfluous, by construction. In other words, we no longer need the time demeaning operation of fixed effects in a dynamic panel data model. The absence of unit effects and the demeaning process also guards against biased parameter estimates, which are present in many dynamic panel and time-series cross-section designs, in which the bias is caused by the correlation between the demeaned LDV and the demeaned error term (Beck and Katz 2011; Nickell 1981). In any event, as Beck and Katz (2011, p. 342) argue, the Nickell bias becomes small as the number of observations becomes sufficiently large. Given that our monthly dataset yields an average number of observations per panel of over 100 , we are relatively confident that the findings shown below are not affected by Nickell bias.

We first present a set of pooled time-series models with a random slope of the LDV. ${ }^{17}$ Since conventional time-series cross-section models produce biased and inconsistent estimates under cross-sectional heterogeneity in the value of autoregressive parameters (Webb and Weinberg 2017), we opt for these mixed effects models to counteract this problem. In essence, we allow the model's adjustment mechanism to vary from country to country, indicated by subscript $i$ under the coefficient $\alpha$ for the LDV.

\footnotetext{
${ }^{14}$ We provide country-by-country time-series results via a coefficient plot of the estimated impact of the austerity dummy and a chronological visualization of country-specific events in Appendix B. We also checked for the appropriate countryspecific lag structure via auto-correlation and partial auto-correlation functions, and found that an AR(1) specification is the appropriate dynamic specification for all countries.

${ }^{15}$ Appendix C-1 displays the distribution of the p-values for country-specific unit-root tests both before and after the filtering.

${ }^{16}$ Due to the filtering in the first step, the country series are mean centered around 0 , eliminating unit- (country-specific) effects from the pooled model.

${ }^{17}$ See Beck and Katz (2007) for a thorough discussion of random-coefficient models estimated by Maximum Likelihood in the context of pooled time-series data. In Appendix D-5, we present the results for the fixed effects and random effects variants of our models.
} 
Our models estimate the average (unconditional) impact of austerity episodes on the transformed cabinet-level vote intention variable. All model specifications are dynamic, so the estimated coefficients of the austerity variable merely serve to indicate the immediate response; the total impact over time is augmented by the long-run multiplier, which is provided by the coefficient of the models' LDV. Our modified step-specification thus allows for the gradual accumulation of the impact of austerity, while the country-specific estimates of the LDV calculated from our random slope models allow for different trajectories of the dependent variable during and after the austerity windows.

\section{Main Results}

Table 1 shows the average (non-conditional) impact of austerity when estimated with three different time windows. Models 1-3 estimate the impact via a bivariate dynamic model, while Models 4-6 add the contextual controls from the three hypotheses as well as an additional economic control of monthly retail sales volume, our proxy for monthly GDP growth.

All models provide strong evidence that austerity, on average, reduces support for government parties, as stipulated by our austerity hypothesis. They also produce significant and broadly similar estimates for the impact of austerity: the initial impact is estimated to be 0.6 to 0.8 percentage points depending on the length of the intervention window and the inclusion/exclusion of the controls. The information criteria (we only show AIC in the table) also indicate very similar model fits, with the 6-month specification performing slightly better than the other windows. As for the control variables, interestingly, neither the macroeconomic indicators (year-on-year change in unemployment and year-on-year growth of retail sales volumes) nor the external creditors' involvement appears to significantly predict government popularity. Our indicator for politicization, by contrast, shows that in periods of higher protest intensity, governments tend to be less popular.

To calculate the total impact of austerity, one needs to consider that the initial impact is augmented by the long-run multiplier during the intervention window before the dependent variable converges back to its pre-austerity equilibrium. We use the 6-month intervention window from Model 5 to perform a dynamic simulation (King, Tomz and Wittenberg 2000) of the impact in the long run. According to the simulation (shown only for the interactive models below), by the end of the intervention window the estimated level of the dependent variable is around 2 percentage points below its value at the beginning of the period. Over time, however, the effect of austerity dissipates, suggesting that the costs of fiscal consolidation are transient. As voters are more likely to respond to short-term economic dynamics than long-term considerations (Achen and Bartels 2016; Healy and Lenz 2014), the memory of austerity can fade. This is in line with the notion that governments strategically time fiscal consolidations in order to minimize the associated electoral costs (Hübscher and Sattler 2017).

Turning to the tests of our hypotheses on context conditions, we proceed in the following manner. We rely on the information criteria for the fully specificed models to select the 6 -month time window as the best performing period. We then use Model 5 with this time window as a benchmark for all subsequent models and add interaction terms one at a time in the order of our hypotheses: unemployment change, external creditor dummy and protest frequency. ${ }^{18}$ In addition to instantaneous effects we also show the total cumulative effect over time via dynamic simulation as above. ${ }^{19}$ Table 2 presents the results.

\footnotetext{
${ }^{18}$ We provide results for the 3-month and 12-month windowns in Appendix D-4.

${ }^{19}$ Since we allow the long-run multiplier to vary according to a random draw from a normal distribution, one could also illustrate the impact using different country-specific LDV coefficients. Appendix C-2 reports the results of a dynamic simulation of the interactions for two countries with high (Hungary) and low (Romania) persistence in the dependent variable according to their country-specific LDV coefficients.
} 
Table 1. Baseline models for the unconditional effects of austerity

\begin{tabular}{|c|c|c|c|c|c|c|}
\hline & \multicolumn{6}{|c|}{ Dependent variable: vote intention } \\
\hline & Model 1 & Model 2 & Model 3 & Model 4 & Model 5 & Model 6 \\
\hline Vote intention $_{t-1}$ & $0.621^{\star \star \star}(0.028)$ & $0.627^{\star \star \star}(0.029)$ & $0.632^{\star \star \star}(0.029)$ & $0.621^{\star \star \star}(0.028)$ & $0.628^{\star \star \star}(0.028)$ & $0.632^{\star \star \star}(0.029)$ \\
\hline Austerity_12m & $-0.590^{\star \star \star}(0.137)$ & & & $-0.626^{\star * *}(0.144)$ & & \\
\hline Austerity_6m & & $-0.732^{\star \star \star}(0.159)$ & & & $-0.729^{\star \star \star}(0.166)$ & \\
\hline Austerity_3m & & & $-0.835^{\star \star \star}(0.203)$ & & & $-0.757^{\star \star \star}(0.209)$ \\
\hline$\Delta$ unemployment & & & & $0.010(0.046)$ & $0.017(0.046)$ & $0.006(0.046)$ \\
\hline Retail growth & & & & $-0.019(0.016)$ & $-0.016(0.016)$ & $-0.014(0.016)$ \\
\hline IMF & & & & $0.244(0.215)$ & $0.189(0.213)$ & $0.138(0.213)$ \\
\hline Protest & & & & $-0.233^{\star * *}(0.052)$ & $-0.220^{\star \star \star}(0.052)$ & $-0.210^{\star \star \star}(0.052)$ \\
\hline (Intercept) & $0.197^{\star *}(0.076)$ & $0.158^{\star}(0.070)$ & $0.104(0.067)$ & $0.284^{\star \star \star}(0.082)$ & $0.232^{\star \star}(0.076)$ & $0.175^{\star}(0.073)$ \\
\hline AIC & $7,955.325$ & $7,952.316$ & $7,956.164$ & $7,959.304$ & $7,958.574$ & $7,964.192$ \\
\hline Num. obs. & 1,674 & 1,674 & 1,674 & 1,674 & 1,674 & 1,674 \\
\hline Num. groups & 15 & 15 & 15 & 15 & 15 & 15 \\
\hline LM test $p$-value & 0.454 & 0.532 & 0.561 & 0.427 & 0.502 & 0.515 \\
\hline AR(1) Std Dev & 0.076 & 0.078 & 0.081 & 0.075 & 0.077 & 0.079 \\
\hline
\end{tabular}

${ }^{\star \star *} p<0.001,{ }^{\star *} p<0.01,{ }^{*} p<0.05,{ }^{\dagger} p<0.1$ 
Table 2. Interactive models accounting for context conditions

\begin{tabular}{|c|c|c|c|}
\hline & \multicolumn{3}{|c|}{ Dependent variable: vote intention } \\
\hline & Model 7 & Model 8 & Model 9 \\
\hline Vote intention $_{t-1}$ & $0.627^{\star \star \star}(0.029)$ & $0.629^{\star \star \star}(0.029)$ & $0.628^{\star \star \star}(0.028)$ \\
\hline Austerity_6m & $-0.577^{\star \star}(0.176)$ & $-0.549^{\star \star}(0.184)$ & $-0.620^{\star \star \star}(0.175)$ \\
\hline$\Delta$ unemployment & $0.083(0.053)$ & $0.024(0.046)$ & $0.021(0.046)$ \\
\hline Retail growth & $-0.016(0.016)$ & $-0.015(0.016)$ & $-0.017(0.016)$ \\
\hline IMF & $0.197(0.213)$ & $0.501^{\star}(0.253)$ & $0.176(0.213)$ \\
\hline Protest & $-0.199^{\star \star \star}(0.052)$ & $-0.209^{\star \star \star}(0.052)$ & $-0.124^{\dagger}(0.072)$ \\
\hline Austerity_ $6 \mathrm{~m} \times \Delta$ unemployment & $-0.186^{\star}(0.073)$ & & \\
\hline Austerity_6m $\times$ IMF & & $-0.918^{\star}(0.404)$ & \\
\hline Austerity_ $6 \mathrm{~m} \times$ protest & & & $-0.182^{\dagger}(0.094)$ \\
\hline (Intercept) & $0.218^{\star \star}(0.076)$ & $0.198^{\star}(0.077)$ & $0.197^{\star}(0.078)$ \\
\hline AIC & $7,957.478$ & $7,955.411$ & $7,959.707$ \\
\hline Num. obs. & 1,674 & 1,674 & 1,674 \\
\hline Num. groups & 15 & 15 & 15 \\
\hline LM test $p$-value & 0.477 & 0.503 & 0.521 \\
\hline AR(1) Std Dev & 0.081 & 0.080 & 0.077 \\
\hline
\end{tabular}

${ }^{\star \star \star} p<0.001,{ }^{* \star} p<0.01,{ }^{*} p<0.05,{ }^{\dagger} p<0.1$

Model 7 allows the effect of austerity to vary with the monthly year-on-year change in the unemployment rate. ${ }^{20}$ The significant interaction term and the marginal effects plot (Figure 1) offer strong evidence in support of our economic conditions hypothesis. In times of declining unemployment rates, the marginal effect of austerity is statistically indinstinguishable from zero. By contrast, when unemployment is stable or increasing, austerity is associated with an ever larger electoral punishment. For instance, under a scenario of stable unemployment (year-on-year $\Delta$ unemployment $=0$ ) followed by an economic shock that results in a 1 per cent year-on-year increase in unemployment for an extended period of time, the immediate impact of austerity for government parties is a 0.76 -percentage-point loss in vote intentions. Using a dynamic simulation, we calculate that this accumulates to a loss of around 1.9 percentage points by the end of the 6-month intervention window (Figure 1). ${ }^{21}$

When examining the interaction between the external involvement dummy and the austerity dummy (the external involvement hypothesis), a rather strong pattern emerges. The interaction term is substantively large $(-0.92)$ and significant, implying a non-trivial difference in the size of the government's punishment depending on whether austerity is implemented under external pressure or not. As the marginal effects plot shown in Figure 2 reveals, externally imposed austerity episodes imply an immediate loss of popularity of around 1.45 percentage points, accumulating to a total estimated loss of 3.58 percentage points by the end of the 6-month intervention window. By contrast, the estimated immediate hit to government parties' vote intention in the wake of domestically driven austerity episodes is considerably more limited: 0.54 percentage points, resulting in a 1.36-percentage-point total loss. The strong interaction dynamics between austerity and external creditors' involvement helps to adjudicate in the debate on the external dimension of responsibility attribution. Far from diluting perceived responsibility and sheltering incumbents from the wrath of the public, the straightjacket imposed by external creditors appears to highlight incumbents' responsibility for economic mismanagement, amplifying punishment in the polls.

\footnotetext{
${ }^{20}$ We provide results with growth in retail sales volume - a close monthly proxy for economic output - rather than unemployment as the conditioning variable in Appendix D-3 and find that the interactive pattern between retail growth and austerity is qualitatively very similar to unemployment, which further corroborates the economic conditions hypothesis.

${ }^{21}$ These estimated averages hide variation in the rates of adjustment between the country-specific series, giving rise to potentially different dynamic effects. We illustrate how these dynamics play out in countries with a quick rate of adjustment (Romania) and a slow rate of adjustment (Hungary) in Appendix C-2.
} 
A Instantaneous effect of austerity_6m

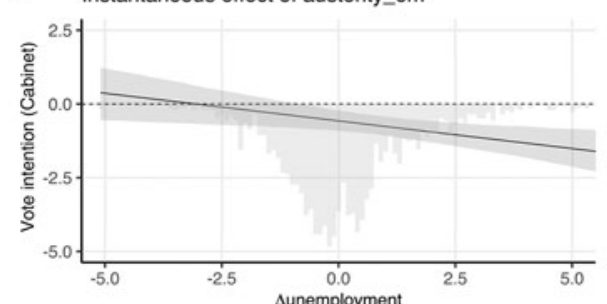

D Impulse response at the 3rd quantile of $\Delta$ unemployment
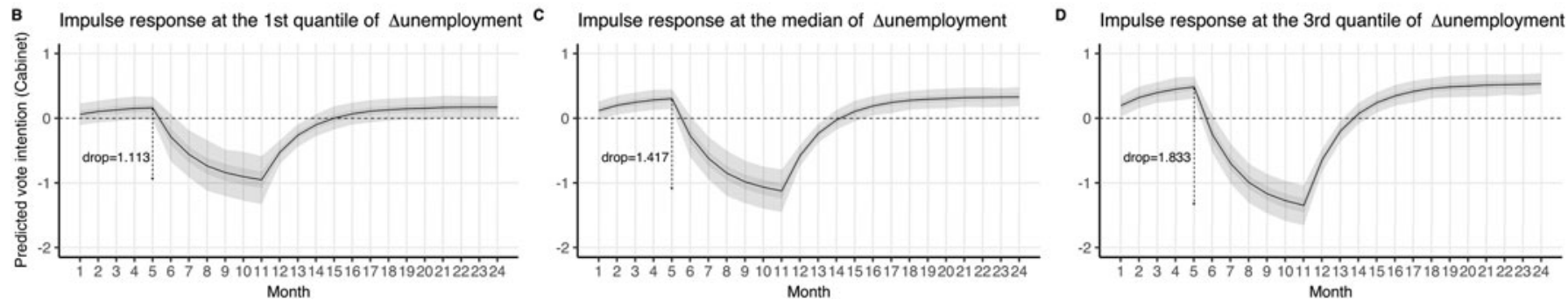

Figure 1. Instantaneous effects and impulse response functions of austerity at different rates of change in the unemployment rate

Note: for the impulse response functions, we simulate the evolution of the dependent variable with a starting value of 0 . 

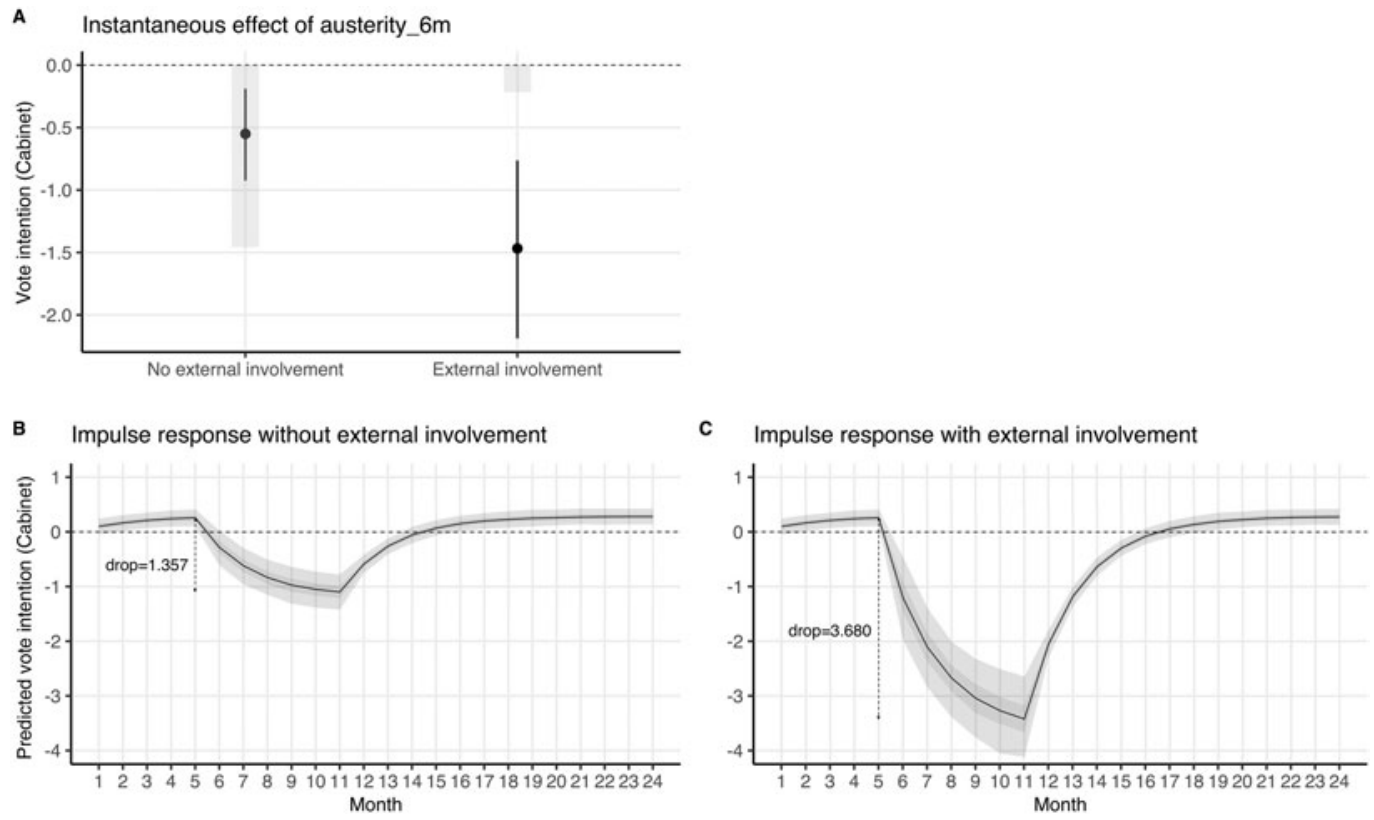

Figure 2. Instantaneous effects and impulse response functions of austerity with and without external creditors' involvement

Finally, we test the politicization hypothesis by introducing the weighted protest frequency variable in interaction with the austerity dummy while keeping the rest of the covariates in the model as controls. ${ }^{22}$ The interactive patterns shown in Figure 3 provide support for the hypothesis. Although the estimated immediate impact of austerity is negative and significant at all levels of protest frequency, its substantive impact is larger in times of high politicization. For instance, when the weighted protest variable is at the 90th percentile of the empirical distribution, the estimated immediate impact is a 0.87 -percentage-point drop, cumulating to a 2.1-percentage-point loss in vote intentions by the end of the 6-month intervention window. By contrast, in instances of no protest (weighted protest frequency $=0$ ), a more modest 0.59 -percentage-point punishment is followed by a 1.52-percentage-point total loss after a 6-month period. Therefore, in line with our expectations, the intensity of protest activity increases the electoral punishment of austerity, though the conditioning role of protest is weaker than the other two contextual covariates (unemployment and external creditors' involvement).

\section{Extension: A Case Study}

While the strength of the pooled analysis that we have produced so far is a high level of generalizability, its inherent weakness is a limited consideration of details. In this penultimate section, we aim to illustrate the impact of austerity by placing individual austerity episodes at the centre stage of analysis in a particular country of choice - Greece. Although the country was a clear outlier in the European austerity saga during the Great Recession, it is interesting for illustrative

\footnotetext{
${ }^{22}$ Recognizing the potentially endogenous nature of our protest frequency measure, we examine the robustness of our results by instrumenting the protest variable via two-stage least squares (shown in Appendix D-3) using the following set of exogenous instruments: left cabinets, honeymoon periods, seasonal dummies and country fixed effects. Endogeneity tests, a weak identification test and a Sargan statistic for overidentification all indicate that our choice of instruments is appropriate. The results show that the interactive patterns with the instrumented protest variable become even stronger.
} 
A Instantaneous effect of austerity $6 \mathrm{~m}$

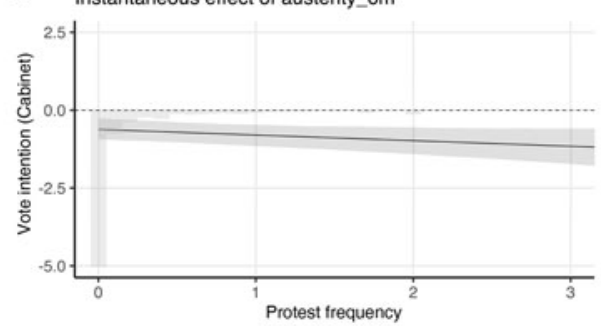

B Impulse response at the $10 \%$ quantile of protest frequency

C Impulse response at the $75 \%$ quantile of protest frequency

D Impulse response at the $90 \%$ quantile of protest frequency
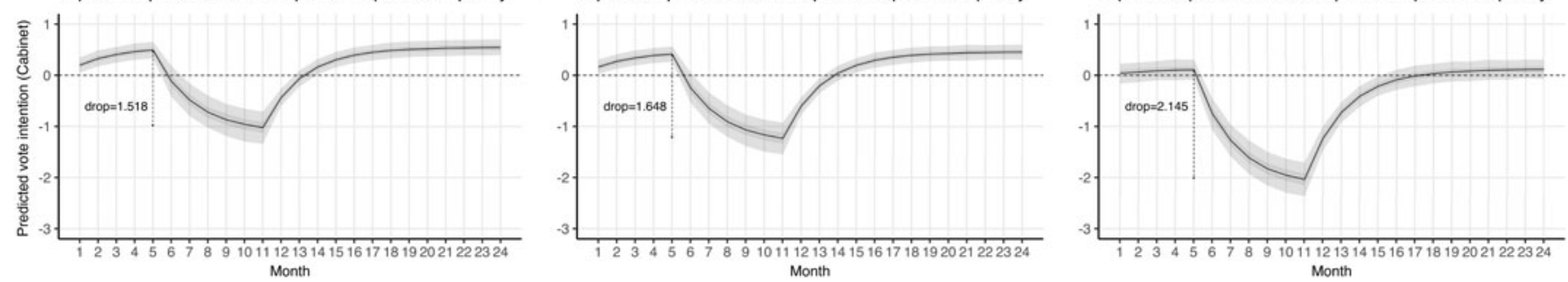

Figure 3. Instantaneous effects and impulse response functions of austerity at different levels of protest frequency 
Table 3. Time-series models for austerity episodes in Greece

\begin{tabular}{|c|c|c|c|c|c|}
\hline & \multicolumn{5}{|c|}{ Dependent variable: vote intention } \\
\hline & Model 10 & Model 11 & Model 12 & Model 13 & Model 14 \\
\hline Vote intention $_{t-1}$ & $0.701^{\star \star \star}(0.071)$ & $0.608^{\star \star \star}(0.071)$ & $0.710^{\star \star \star}(0.068)$ & $0.698^{\star * *}(0.070)$ & $0.674^{\star \star \star}(0.067)$ \\
\hline First_bailout & $0.740(1.415)$ & & & & \\
\hline Mid_term & & $-5.062^{\star \star \star}(1.420)$ & & & \\
\hline Second_bailout & & & $-2.193(1.488)$ & & \\
\hline Third_bailout & & & & $-1.540(1.387)$ & \\
\hline Austerity_6m & & & & & $-2.236^{\star \star \star}(0.753)$ \\
\hline (Intercept) & $-0.048(0.327)$ & $0.279(0.310)$ & $0.096(0.322)$ & $0.080(0.325)$ & $0.475(0.345)$ \\
\hline$R^{2}$ & 0.504 & 0.557 & 0.513 & 0.508 & 0.541 \\
\hline Adj. $R^{2}$ & 0.494 & 0.548 & 0.503 & 0.499 & 0.533 \\
\hline Num. obs. & 107 & 107 & 107 & 107 & 107 \\
\hline RMSE & 3.279 & 3.099 & 3.249 & 3.264 & 3.152 \\
\hline Ljung-Box test $p$-value & 0.311 & 0.176 & 0.401 & 0.277 & 0.187 \\
\hline
\end{tabular}

${ }^{* \star *} p<0.001,{ }^{* \star} p<0.01,{ }^{*} p<0.05,{ }^{\dagger} p<0.1$

purposes because it satisfies all the context conditions that we have shown to amplify the penalty in the polls: austerity packages were adopted under deteriorating economic conditions, high levels of politicization and the strict conditionality of external creditors. This leads us to expect quite dramatic consequences in the polls.

We use the four austerity packages that we included in the pooled models for Greece: the First bailout (May 2010), the Mid-term Adjustment Programme (June 2011), the Second Bailout (February 2012) and the Third Bailout (July 2015). Table 3 presents the estimates for the impact of the individual packages (Models 10-14) as well as for the average impact of austerity measured via a 6-month window for Greece only. The estimates show that, on average, these packages had a highly significant negative effect on the government's popularity (2.24 percentage points for the immediate effect and a total effect above 6 percentage points), significantly above the average impact from the pooled analysis. They also show that, individually, the impact of the different packages varies considerably, partly as a function of context conditionalities highlighted by our pooled analysis and partly due to other developments that are beyond the scope of our results.

For instance, the estimate for the first bailout package is actually positive (non-significant), suggesting that the implementation of the first bailout program had no immediate electoral repercussions for the Greek government. Within our explanatory framework, this is arguably related to the fact that in the spring and summer of 2010, the Greek economy still held up reasonably well with the unemployment rate rising only modestly. Moreover, the frequency of protests paled in comparison to the storm that Greece was yet to experience.

By far the most dramatic drop in the ruling party's (PASOK) popularity followed the implementation of the mid-term adjustment package (a more than 12-percentage-point loss by the end of the period). The episode of the mid-term adjustment saw the rise of new challengers - the Greek Indignados, inspired by events in Spain - that broadened the base of the grassroots mobilization to non-political elites and introduced more confrontational forms of protest. As Altiparmakis (2019) shows, it was at this moment that widespread dissatisfaction with austerity expanded into the political field and focused on the vote for the mid-term adjustment in parliament. This illustrates the effect of protest on the government's popularity. Under enormous pressure from Europe, the mid-term adjustment episode led to the adoption of the 'multi-law' bill in October 2011, which eventually led to the resignation of the PASOK government and its replacement by the technocratic Papademos government that was responsible for adopting the second bailout package in early 2012 .

The substantive estimate for the second bailout package, implemented by the Papademos government, is also large (an immediate 2.2-percentage-point loss and a 6.7-percentage-point total 
drop), but it fails to achieve significance at conventional levels. This lack of significance is arguably due to the short time window for the step function because of the change in government after the June 2012 elections. However, the substantively large estimate for the drop in the popularity of two main parties supporting the Papademos government (PASOK and New Democracy) is testimony to the ever-deteriorating economic situation and unabated protest activity as a carryover from the mid-term adjustment period.

Comparatively speaking, the third bailout agreed upon by the Syriza-led government with international creditors under dramatic circumstances in the summer of 2015 had a lower impact (a non-significant 1.54-percentage-point immediate drop). This bailout episode stands in stark contrast to what had happened earlier during the Greek crisis because it was surprisingly noncontentious. The key event in this episode was the referendum on the new bailout agreement, organized by the newly elected radical left Syriza government. The government campaigned for a No vote (that is, for refusing to sign a new bailout agreement) and achieved a resounding victory. In an astounding turnaround, the Syriza government still proceeded to sign a new agreement with the European partners and the IMF, implementing the third bailout within a week after the referendum. With Syriza's capitulation, the bailout era came to an abrupt end. Contention ended because, among other things, frustration and exhaustion contributed to demobilization (Altiparmakis 2019). In addition, trust in Syriza's leader Alexis Tsipras marked a key difference with the mobilization against PASOK, even after the end of the negotiations: to the Greek public, the new prime minister appeared to have done everything he could to avoid the inevitable and he was thus spared the blame for the turn of events. The limited impact of this episode on the government's popularity can be explained by a combination of the effectiveness of Tsipra's rhetoric, the wavering of the internal opposition, and the despair and defeat of the official opposition, which all played into the government's hands.

\section{Conclusion}

As EU countries are experiencing another severe recession as a result of the COVID-19 pandemic, it is important to take stock of the political aftermath of the financial crisis and the eurozone crisis. In this article, we made an important contribution to this effort by conducting a systematic statistical analysis of the electoral impact of some of the most contentious economic policy decisions that governments have taken to address the fiscal imbalances resulting from the twin crises. We analysed the effects of the most important austerity packages and structural reforms that governments implemented on government popularity. In the spirit of the interrupted time-series literature, we treated these packages as external shocks to the underlying times series that describe the monthly vote intention shares of ruling parties in fifteen European countries between 2005 and 2015.

To recap the main findings, we showed that while economic aggregates have little independent explanatory power on governments' popularity during the Great Recession, governments are routinely held accountable for contentious economic policy decisions, as measured by the evolution of the support for ruling parties in opinion polls (cf. Malet and Kriesi 2020). By moving closer to the actual policy packages, we were able to closely track the political effects of austerity, and we modelled this impact via intervention windows (step dummies of various lengths). Contrary to the literature on the fiscally conservative voter, this approach allowed us to show that, on average, austerity packages had a significant and substantively important negative effect on governments' monthly vote intention ratings. The costs of austerity, however, are transient and depend on political and economic context conditions: overall, we found that government popularity declines for roughly one year and that this decrease is substantial if there are large increases in unemployment, external pressures from creditors and high politicization of economic conflicts in the streets. 
The implications of these findings are at least twofold. On the one hand, they help us to make sense of the political consequences of the Great Recession. As austerity became the dominant macroeconomic policy in post-crisis Europe, we witnessed the successful rise of anti-austerity parties, movements and politicians in some countries but not in others. Our results suggest that austerity, on average, is costlier than the conventional literature assumes, while highlighting the conditions under which we can expect austerity packages to especially harm the popularity of governments and influence their re-election chances. Some governments were not only able to strategically time austerity policies (Hübscher and Sattler 2017); they were also able to rely on favourable economic and political conditions to avoid electoral punishment (for example, the Conservatives in the UK). Amid pressure from external creditors, other governments were unable to do this, which contributed to different political consequences of the Great Recession across the continent (Hutter and Kriesi 2019).

On the other hand, the findings help us understand voters' responses to economic processes more generally. In the search for the aggregate economic vote, the article turned from economic conditions (output) to economic policies (input). This approach allowed us to unearth effects that may remain hidden when focusing exclusively on election results. Our results suggest that voters are nuanced. Even if transient in nature, the electorate's response to sensitive policies does not follow the reward-punishment hypothesis in a straightforward, linear fashion in the short run but is highly conditional on the context. By assigning reward and blame to policies rather than economic aggregates, voters hold incumbents accountable for the levers under incumbents' direct control rather than for the vagaries of the ever more interdependent globalized markets.

Supplementary material. Online appendices are available at https://doi.org/10.1017/S0007123420000472

Acknowledgments. The authors acknowledge funding by the ERC project Political Conflict in Europe in the Shadow of the Great Recession (POLCON) (Project id: 338875). Previous versions of this article were presented at the 2018 annual SASE conference, the 2019 SPSA annual conference and Dreiländertagung, and at workshops at the European University Institute (EUI), Sciences Po Paris, and the Max Planck Institute for the Study of Societies, Cologne. We are very grateful for insightful comments that we received at each occasion, and we specifically thank Lukas Haffert, Thomas Sattler, Liisa Talving, four anonymous reviewers, and the editors of the BJPolS for excellent feedback. All remaining errors remain our own.

Data availability statement. Data replication files are available at: https://doi.org/10.7910/DVN/MDLQKC

\section{References}

Achen CH and Bartels LM (2016) Democracy for Realists. Princeton, NJ: Princeton University Press.

Alesina A and Ardagna S (1998) Tales of fiscal adjustment. Economic Policy 13, 489-585.

Alesina A, Favero C and Giavazzi F (2019) Austerity: When It Works and When it Doesn't. Princeton, NJ: Princeton University Press.

Alesina A et al. (1998) The political economy of fiscal adjustments. Brookings Papers of Economic Activity 1998, 197-248. Altiparmakis A (2019) The Age of the Bailout. PhD thesis. Florence: European University Institute.

Altiparmakis A and Lorenzini J (2018) Disclaiming national representatives: protest waves in Southern Europe during the crisis. Party Politics 24, 78-89.

Anderson CJ (2007) The end of economic voting? Contingency dilemmas and the limits of democratic accountability. Annual Review of Political Science 10, 271-296.

Arias E and Stasavage D (2019) How large are the political costs of fiscal austerity? Journal of Politics 81, 1517-1522.

Armingeon K (2012) The politics of fiscal responses to the crisis 2008-2009. Governance 25, 543-565.

Armingeon K and Giger N (2008) Conditional punishment: a comparative analysis of the electoral consequences of welfare state retrenchment in OECD nations, 1980-2003. West European Politics 31, 558-580.

Barnes L and Hicks T (2018) Making austerity popular: the media and mass attitudes toward fiscal policy. American Journal of Political Science 62, 340-354.

Bartels LM (2014) Ideology and retrospection in electoral responses to the Great Recession. In Bermeo N and Bartels B (eds), Mass Politics in Tough Times. Opinions, Votes, and Protest in the Great Recession. Oxford: Oxford University Press, pp. 1-39.

Bechtel MM, Hainmüller J and Margalit Y (2017) Policy design and domestic support for international bailouts. European Journal of Political Research 56, 864-886.

Beck N and Katz JN (2007) Random coefficient models for time-series-cross-section data: Monte Carlo experiments. Political Analysis 15, 182-195. 
Beck N and Katz JN (2011) Modelling dynamics in cross-section-time-series political economy data. Annual Review of Political Science 14, 331-352.

Beissinger MR and Sasse G (2014) An end to 'patience'? The Great Recession and economic protest in Eastern Europe. In Bermeo N and Bartels B (eds), Mass Politics in Tough Times: Opinions, Votes, and Protest in the Great Recession. Oxford: Oxford University Press, pp. 334-370.

Bellucci P (2014) The political consequences of blame attribution for the economic crisis in the 2013 Italian national election. Journal of Elections, Public Opinion and Parties 24, 243-263.

Bellucci P and Lewis-Beck MS (2011) A stable popularity function? Cross-national analysis. European Journal of Political Research 50, 190-211.

Bisgaard M and Sloothus R (2018) Partisan elites as culprits? How party cues shape partisan perceptual gaps. American Journal of Political Science 62, 456-469.

Blinder AS and Holtz-Eakin D (1984) Public opinion and the balanced budget. The American Economic Review 74, 144-149.

Bojar A, Bremer B, Kriesi H and Wang C (2020) Replication Data for: The Effect of Austerity Packages on Government Popularity during the Great Recession. https://doi.org/10.7910/DVN/MDLQKC, Harvard Dataverse, V1, UNF:6: yW4ii5pV2la0NuXBQap9Nw== [fileUNF].

Bremer B, Hutter S and Kriesi H (2020) Dynamics of protest and electoral politics in the Great Recession. European Journal of Political Research. Doi: 10.1111/1475-6765.12375

Brender A and Drazen A (2008) How do budget deficits and economic growth affect reelection prospects? Evidence from a large panel of countries. American Economic Review 98, 2203-2220.

Clarke HD, Ho K and Stewart MC (2000) Major's lesser (not minor) effects: prime ministerial approval and governing party support in Britain since 1979. Electoral Studies 19, 255-274.

Clarke HD and Whitten GD (2013) Hard choices in hard times: valence voting in Germany (2009). Electoral Studies 32, 445-451.

Dassonneville, R. and Michael S. Lewis-Beck (2014) Macroeconomics, economic crisis and electoral outcomes: A national European pool. Acta Politica (49): 372-394.

De Boef S (2001) Modelling equilibrium relationships: error correction models with strongly autoregressive data. Political Analysis 9, 78-94.

De Boef S and Keele L (2008) Taking time seriously. American Journal of Political Science 52, 184-200.

Duch RM and Stevenson RT (2008) The Economic Vote. How Political and Economic Institutions Condition Election Results. New York: Cambridge University Press.

Earl J et al. (2004) The use of newspaper data in the study of collective action. Annual Review of Sociology 30, 65-80.

Enders W (2004) Applied Econometric Time Series. New York: John Wiley \& Sons, Inc.

Fernández-Albertos J and Kuo A (2016) Economic hardship and political preferences in the eurozone periphery: evidence from Spain. Comparative Political Studies 49, 874-906.

Fraile M and Lewis-Beck MS (2014) Economic vote instability: endogeneity or restricted variance? Spanish panel evidence from 2008 and 2011. European Journal of Political Research 53, 160-179.

Gamson WA and Meyer DS (1996) Framing political opportunity. In McAdam D, McCarthy JD and Zald MN (eds), Comparative Perspectives on Social Movements: Political Opportunities, Mobilizing Structures, and Cultural Framings. Cambridge: Cambridge University Press, pp. 275-290.

Giavazzi F and Pagano M (1990) Can Severe Fiscal Contractions be Expansionary? Tales of Two Small European Countries. Working Paper no. 3372. Cambridge, MA: National Bureau of Ecomomic Research.

Golden DG and Poterba JM (1980) The price of popularity: the political business cycle reexamined. American Journal of Political Science 24, 696-714.

Healy A and Lenz S (2014) Subsituting the end for the whole: why voters respond primarily to the election-year economy. American Journal of Political Science 58, 31-47.

Hellwig T (2001) Interdependence, government constraints, and economic voting. Journal of Politics 63, 1141-1162.

Hellwig T and Samuels D (2007) Voting in open economies: the electoral consequences of globalization. Comparative Political Studies 40, 283-306.

Hernández E and Kriesi $\mathbf{H}$ (2016) The electoral consequences of the financial and economic crisis in Europe. European Journal of Political Research 55, 203-224.

Hübscher E and Sattler T (2017) Fiscal consolidation under electoral risk. European Journal of Political Research 56, $151-168$.

Hübscher E, Sattler T and Wagner M (2018) Voter responses to fiscal austerity. Paper presented at the Annual Meeting of the European Political Science Association, Vienna, 21-23 June.

Hutter S and Grande E (2014) Politicizing Europe in the national electoral arena: a comparative analysis of five West European countries, 1970-2010. Journal of Common Market Studies 52, 1002-1918.

Hutter S and Kriesi H (2019) European Party Politics in Times of Crisis. Oxford: Oxford University Press.

Jensen NM and Rosas G (2020) Open for politics? Globalization, economic growth, and responsibility attribution. Journal of Experimental Political Science 7, 89-100. 
Kayser MA and Peress M (2012) Benchmarking across borders: electoral accountability and the necessity of comparison. American Political Science Review 106, 661-684.

King G, Tomz M and Wittenberg J (2000) Making the most of statistical analyses: improving interpretation and presentation. American Journal of Political Science 44, 347-361.

Kosmidis S (2018) International constraints and electoral decisions: does the room to maneuver attenuate economic voting? American Journal of Political Science 62, 519-534.

Lebo MJ and Young E (2009) The comparative dynamics of party support in Great Britain: Conservatives, Labour and the Liberal Democrats. Journal of Elections, Public Opinion and Parties 19, 73-103.

Lewis-Beck MS and Paldam M (2000) Economic voting: an introduction. Electoral Studies 19, 113-121.

Lewis-Beck MS and Stegmaier M (2013) The VP-function revisited: a survey of the literature on vote and popularity functions after over 40 years. Public Choice 157, 367-385.

Lorenzini J, Makarov P and Wuest B (2020) Design and methods of the semi-automated protest event analysis. In Kriesi H, Lorenzini J, Wuest B and Hausmermann S (eds), Contention in Times of Crisis: Comparing Political Protest in 30 European Countries, 2000-2015. Cambridge: Cambridge University Press.

MacKuen M, Erikson R and Stimson J (1992) Peasants or bankers? The American electorate and the US economy. American Political Science Review 86, 597-611.

Magalhaes PC (2014) The elections of the Great Recession in Portugal: performance voting under a blurred responsibility for the economy. Journal of Elections, Public Opinion 24, 180-202.

Malet G and Kriesi H (2020) Economic shocks and the cost of ruling: evidence from Italy. Journal of Elections, Public Opinion, and Parties 30, 22-41.

Marsh M and Mikhaylov S (2012) Economic voting in a crisis: the Irish election of 2011. Electoral Studies 31, 478-484.

McDowall D et al. 1980) Interrupted Time Series Analysis. Thousand Oaks, CA: Sage Publications.

Nickell S (1981) Biases in dynamic models with fixed effects. Econometrica 49(6), 1417-1426.

Nordhaus, WD (1975) The political business cycle. The Review of Economic Studies 42, 169-190.

Pankratz A (1991) Forecasting with Dynamic Regression Models. New York: John Wiley \& Sons, Inc.

Peltzman S (1992) Voters as fiscal conservatives. The Quarterly Journal of Economics 107, 327-361.

Pickup M (2010) Better know your dependent variable: a multination analysis of government support measures in economic popularity models. British Journal of Political Science 40, 449-468.

Pierson P (1996) The new politics of the welfare state. World Politics 48, 143-179.

Pierson P (2001) The New Politics of the Welfare State. Oxford: Oxford University Press.

Pontusson J and Raess D (2012) How (and why) is this time different? The politics of economic crisis in Western Europe and the United States. Annual Review of Political Science 15, 13-33.

Schattschneider EE (1960[1975]) The Semi-Sovereign People: A Realist's View of Democracy in America. New York: Holt, Rinehart and Winston.

Stegmaier M, Lewis-Beck MS and Park B (2017) The VP-function: a review. In Arzheimer K, Evans J and Lewis-Beck MS (eds), The Sage Handbook of Electoral Behavior. Thousand Oaks, CA: Sage Publications, pp. 584-605.

Stimson JA (2004) Tides of Consent: How Public Opinion Shapes American Politics. Cambridge: Cambridge University Press.

Talving L (2017) The electoral consequences of austerity: economic policy voting in Europe in times of crisis. West European Politics 40, 560-583.

Veiga FJ and Veiga LG (2004) The determinants of vote intentions in Portugal. Public Choice 118, 341-364.

Webb C and Weinberg J (2017) It is about time: cross-sectional dynamic heterogeneity in TSCS data. Paper presented at the annual meeting of the Society for Political Methodology, University of Wisconsin-Madison, 13-15 July.

Cite this article: Bojar A, Bremer B, Kriesi H, Wang C (2022). The Effect of Austerity Packages on Government Popularity During the Great Recession. British Journal of Political Science 52, 181-199. https://doi.org/10.1017/S0007123420000472 